\title{
The Development of Teaching Materials for The Principles of Non-formal Education Based on Higher Order Thinking Skills
}

\author{
Yusnadi $^{1^{*}}$, Rosdiana $^{2}$, Anifah $^{3}$ \\ ${ }^{1,2,3)}$ Nonformal Education, Universitas Negeri Medan, Indonesia \\ *yusnadi1961@gmail.com
}

\begin{abstract}
This research aims at generating: (1) the procedure of teaching material development (handbook) for the principles of non formal education based on higher order thinking skills, and (2) the teaching materials for the principle of non formal education based on higher order thinking skills that was valid to be used in learning process. With this purpose, the research was conducted using research and development methods. This research was held for 3 months at the Faculty of Education, Medan State University. The data was collected through a survey that was constructed by the appraisement of teaching materials for the principles of non formal education based on higher order thinking skills from validator experts, language experts, instructional experts and students. The data was analyzed using descriptive-quantitative approach. The results of this research were (1) the procedure of teaching material development for the principles of non formal education based on higher order thinking skills were valid to be used, and (2) The teaching materials of the principles of non formal education were valid to be used in learning process for the subject of the principles of non formal education.
\end{abstract}

Keywords: teaching materials, non-formal education, higher order thinking skills

\section{Introduction}

Education plays an important role in preparing human resources for the development of a nation. Human resources are closely related to the education index. Based on data from the Education For All (EFA) Global Monitoring Report in 2011 issued by UNESCO, Indonesia's education development index is ranked 69th out of 127 . One reason for the low learning achievement is due to the still poor learning process in Indonesia. In the learning process, students are less encouraged to develop thinking skills [1]. Though the ability to think at a higher level is a very important aspect in the teaching and learning process.

Entering the era of the industrial revolution 4.0, education is required to produce graduates who have high-level thinking skills, which are characterized by the ability to think critically, analytically, and creatively. High-level thinking is the ability to connect, manipulate, and transform the knowledge and experience already possessed to think critically and creatively in an effort to determine decisions and solve problems in new situations. Higher-order thinking skills include analytical, evaluation and creative abilities [2]. This is because high-level thinking ability influences students' ability to learn and the effectiveness of learning so that learning objectives can be achieved. Research conducted by Heong, et al said that the ability to think at a higher level has a positive influence in developing students' ability to solve problems [3]. Because of the importance of high-level thinking skills for students, efforts are needed to achieve them. The efforts are meant between through the selection and 
use of appropriate learning models to train students in higher-order thinking. Or also through packaging teaching materials that are oriented to the development of higher-order thinking skills. Several studies have shown that higher-order thinking skills in the medium category can be improved by using problem-based learning models [4]. Likewise, efforts to package teaching materials or literature based on higher order thinking will be able to improve students' higher level thinking skills [5]

With reference to the demands of high-level thinking skills in learning, the Faculty of Education since 2018/2019 has used the Indonesia National Qualification Framework Based Curriculum (KKNI) and has now been integrated with the Industrial Revolution 4.0. This curriculum requires all lectures to be able to support the realization of higher-level thinking skills, including learning materials used in the PLS Fundamentals course. But it has been found that teaching materials in the form of textbooks that are used are not yet based on higher-order thinking skills. Teaching materials do not bring active, creative, and innovative students, instead they only condition students to be more passive, tend to listen, memorize and record lecture material, and even only expect to receive a copy of power point from the lecturer. In terms of lecturers, lecturers are still dominant compared to students in the learning process, consequently learning still tends to develop memory and memorization. Students are still experimenting a little in the learning process so that the development of higher-order thinking skills cannot take place optimally.

The learning material that is characterized as described does not appear to be inherent in the Basic Fundamentals of Non-School Education, even though this subject is a compulsory subject for all first semester students within the Faculty of Education. Learning often takes place centered on educators, students still often learn individually, activities are still low, and the learning model used is still not appropriate, meaning that learning is not oriented towards higher-order thinking skills [6]. Teaching materials should be oriented towards the realization of manipulation skills, and change the knowledge and experience students have and are critical and creative in determining decisions to solve problems in new situations [7]. By developing higher-order thinking skills to students, students will be able to use their knowledge and skills to solve problems in their lives critically. This condition is possible because high-level thinking is a way of thinking that not only remembers and applies but also analytical and creative thinking. In addition to high-level thinking skills in learning is the application of thought processes to complex situations and have many variables. The phenomena and facts found are the basic foundation for an in-depth study of the existence of learning tools, including teaching materials used.

Even though teaching materials are already available provided by the Expertise Lecturer Group (KDBK), but when studied in depth still does not meet the provisions and expectations as standardized learning material in terms of validity, and effectiveness to support learning objectives, especially in developing level thinking skills high. Meanwhile, learning materials must be able to bring students to think analytically, critically and creatively, which leads to the development of high-level thinking skills among students. That learning often takes place centered on educators, students still often learn individually, activities are still low, and the learning model used is still not appropriate. These findings can be ascertained that learning is not oriented to higher-order thinking skills (analytical, critical, and creative and able to provide conclusions or problem solving [6].

If teaching materials are not based on higher-order thinking skills, it can lead to the unpreparedness of graduates to overcome various problems that arise in life, because of the degree to which they are unskilled in analyzing, evaluating and creating and solving various problems that occur. It is this background that underlies that teaching materials must be 
guaranteed their feasibility to produce graduates who are capable of analyzing, critical, and creative.

\section{Research Method}

The study was designed using the Research \& Development (R\&D) method. R\&D is a process used to develop and validate educational products [8]. In this research and development, the product to be developed is teaching material for Fundamentals of NonSchool Education. The development of teaching materials for the basics of High School Education based on higher order thinking skills is carried out using research and development methods that refer to the Borg and Gall model combined with the learning development model used by Dick \& Carey [9]. It was concluded that, the stages used consisted of four stages. The first stage of analysis, which consists of analyzing the needs and characteristics of students. The second stage is design and design, which consists of writing a text for teaching materials based on higher order thinking skills. The third stage of development, which consists of validating the material team, linguists, and instructional experts. The Fourth Stage is product trials, which consist of individual trials of 3 people, small group trials of 9 people, and limited field trials of 30 people. To analyze the results of data validation of teaching materials is done in quantitative descriptive, by looking at the assessment of the feasibility of teaching materials from the results of the study. The quality of the feasibility of developing teaching materials that are developed can be seen from the evaluation of the expert team's validators on teaching materials. Material expert validators, linguists and presentation experts provided answers to the question statements. The questionnaire was arranged in the form of a Likert scale with a score of 1-4, as in Table 1.

Table 1. Teaching Material Feasibility Assessment Standards

\begin{tabular}{ll}
\hline Interval Score & Eligibility Criteria \\
\hline $3,50-4,00$ & Very eligible \\
$3,00-3,49$ & Eligible without revision \\
$2,50-2,99$ & Eligible with revision \\
$2,00-2,49$ & Less eligible need revision \\
$1,00-1,99$ & Not eligible \\
\hline
\end{tabular}

Then calculate the percentage score of teaching materials developed using the reference as follows:

$$
\mathrm{P}=\frac{\mathrm{f}}{\mathrm{N}} \times 100 \%
$$

Note:

$\mathrm{P}=$ score percentage

$\mathrm{f}=$ score achieved

$\mathrm{N}=$ maximum score

For determining the validation criteria the following references are used:

a. Determine the ideal score (maximum), which is $100 \%$

b. Determine the minimum ideal score percentage, which is $25 \%$

c. Determine the range, which is $100 \%-25 \%=75 \%$

d. Determine the interval class, which is 4 ranges (very valid, valid, less valid, and invalid)

e. Determine the length of the interval, i.e. $75: 4=18,75 \%$ 
Table 2. Qualification of Validity of Teaching Materials

\begin{tabular}{ll}
\hline Achievement level & Validity classification \\
\hline $81,26 \%<\mathrm{P} \leq 100 \%$ & Very valid \\
$62,26 \%<\mathrm{P} \leq 81,25 \%$ & valid \\
$43,76 \%<\mathrm{P} \leq 62,25 \%$ & Less valid \\
$25 \%<\mathrm{P} \leq 43,75 \%$ & Invalid \\
\hline
\end{tabular}

\section{Results and Discussion}

The results of the validation of material experts on teaching materials based on high-level thinking skills developed showed that: (1) the quality of the content worthiness was stated to be very valid, with a percentage of $89.28 \%$; (2) the quality of the presentation is stated to be very valid with a percentage of $83.33 \%$; (3) the quality of language from teaching materials is declared valid with a percentage of $75 \%$. Likewise, the quality of image selection is declared valid with a percentage score of $75 \%$. Then the percentage of results assessed by material experts will be presented in Table 1.

\begin{tabular}{lcccc}
\multicolumn{5}{c}{ Table 1. Average Percentage of Assessment Results by Material Experts } \\
\hline $\begin{array}{l}\text { Aspect of } \\
\text { assessment }\end{array}$ & $\begin{array}{c}\text { Assessment } \\
\text { number }\end{array}$ & $\begin{array}{c}\text { Score } \\
\text { percentage }\end{array}$ & $\begin{array}{c}\text { Average } \\
\text { percentage }\end{array}$ & Criteria \\
\hline Eligibility of & 1 & $100 \%$ & & \\
content & 2 & $100 \%$ & & \\
& 3 & $100 \%$ & $89,28 \%$ & Very valid \\
& 4 & $75 \%$ & & \\
& 5 & $75 \%$ & & \\
Display & 6 & $75 \%$ & & \\
& 7 & $100 \%$ & & \\
& 8 & $100 \%$ & & \\
& 9 & $75 \%$ & & \\
Linguistics & 10 & $75 \%$ & & Valid \\
& 11 & $75 \%$ & & \\
Selection of & 12 & $75 \%$ & $83,33 \%$ & \\
fogure & 13 & $75 \%$ & & \\
\hline & 14 & $75 \%$ & $75 \%$ & Valid \\
\hline
\end{tabular}

Based on the analysis of data from Table 1, it can be concluded that the average percentage of the results of the assessment of teaching materials Basic Fundamentals of Education Outside the High Level Thinking Skills are valid with an average score of $80.65 \%$. The percentage diagram of the results of expert material assessment can be seen in Figure 1 Diagram. 


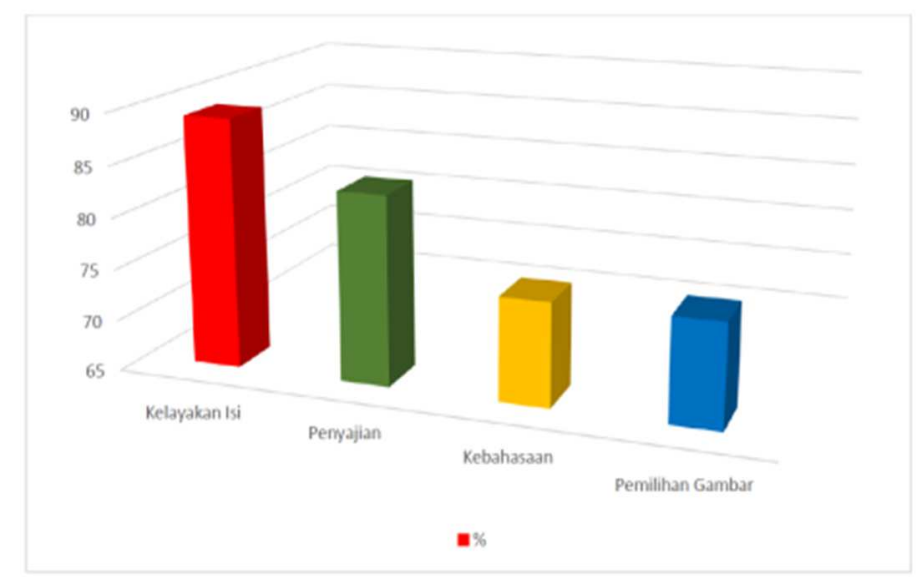

Figure 1. Average Percentage Diagram of Material Expert Assessment Results

With reference to the results of the assessment of the material, there are a number of things that need to be improved, among which there are several concepts from each chapter that need to be revised especially in relation to the development of higher-order thinking skills. Spelling or writing needs to be revised in accordance with the Indonesian spelling, and eliminate illustrations that are not closely related to the scientific aspects of a teaching material. Then, after the revision, the material expert stated that the developed teaching material was appropriate to be used for lectures on the Basics of Non-School Education, especially in relation to the development of students' thinking skills. Then the revision was also made with the addition of the Law on National Education System, as well as the improvement of the cover to make it more interesting.

Table 2. Average Percentage of Language Experts Assessment Results

\begin{tabular}{llcrcl}
\hline No & $\begin{array}{l}\text { Aspect of } \\
\text { assessment }\end{array}$ & $\begin{array}{c}\text { Indicator } \\
\text { number }\end{array}$ & $\begin{array}{r}\text { Percentage } \\
\text { score }\end{array}$ & $\begin{array}{l}\text { Average } \\
\text { percentage }\end{array}$ & Criteria \\
\hline 1 & Linguistics & 1 & $100 \%$ & & \\
& & 2 & $100 \%$ & 91,66 & Very valid \\
& & 3 & $100 \%$ & & \\
& & 5 & $75 \%$ & & \\
& & 6 & $75 \%$ & & \\
2 & Acuracy of & 7 & $75 \%$ & & \\
& language & 8 & $100 \%$ & & \\
& & 9 & $75 \%$ & & \\
& & 10 & $100 \%$ & & \\
& & 11 & $100 \%$ & & \\
& & 12 & $100 \%$ & & \\
3 & Conformity with & 13 & $75 \%$ & 91,6 & Very valid \\
& student & 14 & $100 \%$ & & \\
\hline & development & & & 92,75 & Very valid \\
\hline
\end{tabular}


The results of language validation of teaching materials based on higher-order thinking skills developed show that: (1) the use of language is very valid, with a percentage of $91.66 \%$; (2) language accuracy is very valid with a percentage of $95.00 \%$; (3) conformity with the development of students is declared very valid with a percentage of $91,60 \%$.

By referring to the results of the assessment of linguists, it appears that teaching materials for PLS-Based Higher Level Thinking Skills developed are in the very valid category. Thus, from the analysis of these data it can be concluded that the percentage of an average assessment of the aspects of the language of teaching materials developed is very valid with an average score of $92.75 \%$.

Figure 2 shows the average percentage of the results of the linguist's assessment of the language aspects of teaching materials. The basics of PLS-based Higher Level Thinking Skills are developed.

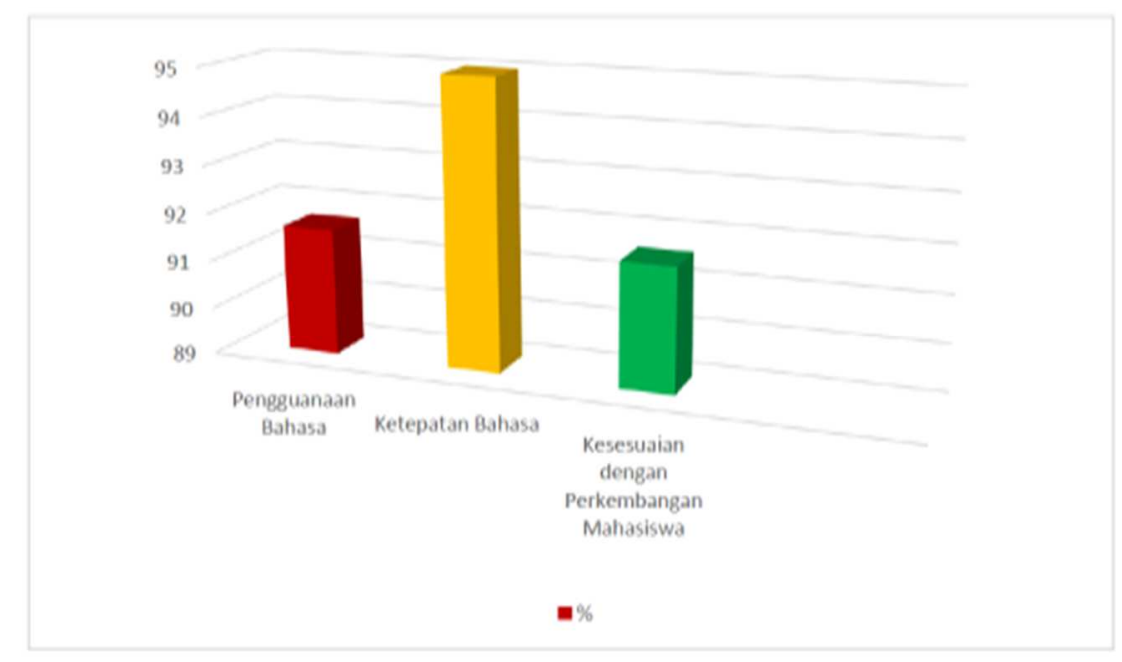

Figure 2. Average Percentage Diagram Results of Linguists' Assessment

There are some things that need to be improved according to the views of linguists regarding the teaching material developed. In terms of sentence structure, it needs improvement, it is required to use standard Indonesian, simplify sentences, writing must be adjusted to the Indonesian Spelling General Guidelines (PUEBI). Then, after the revision was made, according to linguists the teaching material developed could already be used in terms of linguistic aspects.

The results of the validation of the presentation or learning expert on teaching materials for the basics of High Level Thinking Based School Education that were developed showed that: (1) in quality, the presentation of teaching material was seen from the feasibility of very valid serving with a percentage of $84,37 \%$; (2) the quality of the presentation of teaching material is considered valid with a percentage of $75 \%$; (3) the quality of teaching material presentation in terms of language is considered to be very valid with a percentage of $83,33 \%$; and (4) the quality of the presentation of teaching material as seen from the selection of pictures is also valid with a percentage of $75 \%$. The results of the assessment by the experts presenting the material are presented in Table 3. 
Table 3. Average Percentage of Assessment Results by Presentation Experts

\begin{tabular}{|c|c|c|c|c|c|}
\hline No & Aspect of assessment & $\begin{array}{l}\text { Indicator } \\
\text { number }\end{array}$ & $\begin{array}{c}\text { Score } \\
\text { percentage }\end{array}$ & $\begin{array}{l}\text { Average } \\
\text { percentage }\end{array}$ & Criteria \\
\hline \multirow[t]{8}{*}{1} & Eligibility of content & 1 & $100 \%$ & & \\
\hline & & 2 & $100 \%$ & & \\
\hline & & 3 & $100 \%$ & & \\
\hline & & 4 & $75 \%$ & $84,37 \%$ & Very valid \\
\hline & & 5 & $75 \%$ & & \\
\hline & & 6 & $75 \%$ & & \\
\hline & & 7 & $75 \%$ & & \\
\hline & & 8 & $75 \%$ & & \\
\hline \multirow[t]{2}{*}{2} & Display & 9 & $75 \%$ & & \\
\hline & & 10 & $75 \%$ & $75 \%$ & valid \\
\hline \multirow[t]{3}{*}{3} & Linguistics & 11 & $75 \%$ & & \\
\hline & & 12 & $100 \%$ & 83,33 & Very valid \\
\hline & & 13 & $75 \%$ & & \\
\hline \multirow[t]{2}{*}{4} & Selection of figure & 14 & $75 \%$ & $75 \%$ & valid \\
\hline & & 15 & $75 \%$ & & \\
\hline \multicolumn{2}{|c|}{ Percentage of score } & & & 79,42 & valid \\
\hline
\end{tabular}

By referring to the data in Table 3, it can be concluded that the average percentage of assessment results on the presentation of teaching materials based on high-level thinking skills is in the valid category with an average score of $79.42 \%$. The percentage of the results of the assessment by the design expert is visualized in Figure 3.

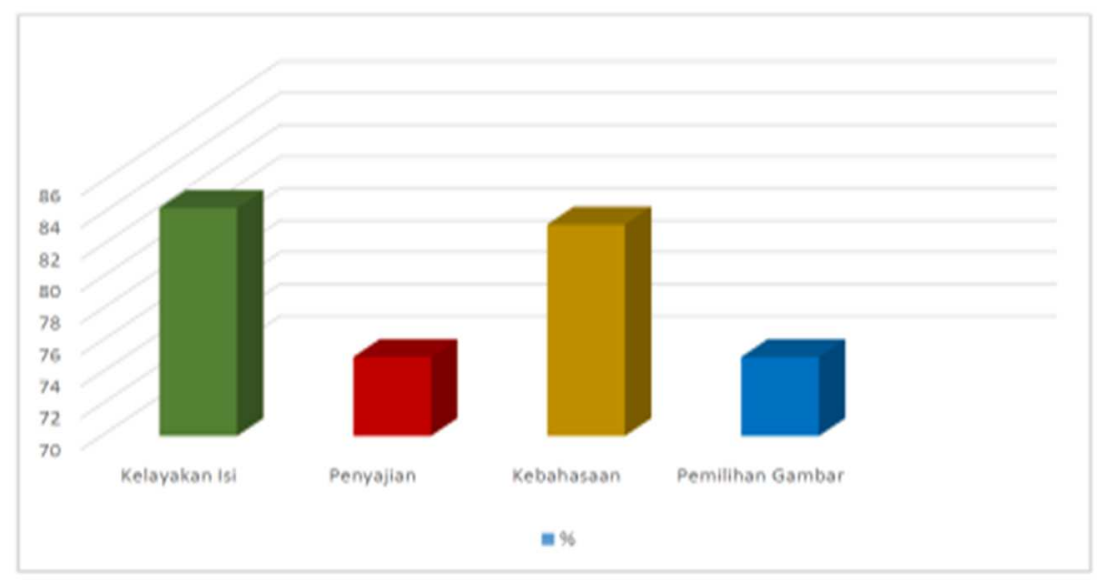

Figure 3. Diagram of Average Percentage of Assessment Results by Designer

By referring to Figure 3 the results of the assessment of the learning design by the presentation expert suggest the need for improvement, including: (1) the PLS concept needs to be added functions and benefits of the PLS, (2) it needs to add the PLS work concept in the PLS population, and (4) clarify HOTS on the material presentation. The results of the corrections to the correction provided by the presentation expert, then the presentation expert 
stated that the developed teaching material can already be used in the field without having to be revised and valid.

The final product of the development of this research is the teaching material in the form of textbooks that have fulfilled various requirements to develop higher-order thinking skills for the Fundamentals of Basic Education. At the stage of developing teaching materials validation is done by linguists, material experts, presenting experts stating that teaching materials for Basic Education Levels Based on Higher Level Thinking Skills that are developed at the final stage are worth using in the field without having to be revised again.

Teaching materials that are designed based on high-level thinking skills will guide students to have skills in solving problems, and will help students to have the skills to participate in learning, both individually and in groups. This is because teaching materials based on high-level thinking skills train students to find problems critically. With high-level thinking skills-based teaching materials will bring students to get used to in; (1) analyzing, which is related to cognitive processes; and (2) evaluating, which is related to cognitive processes in providing judgment [10]. This condition is supported by constructivism learning theory which confirms that students learn to construct their knowledge through interaction with their environment. Learning by using teaching materials based on high-level thinking can actually make students learn through problem solving efforts. Learning with teaching materials based on higher-order thinking skills requires students to actively criticize in solving problems. Teaching materials used in learning like this will be able to form high-level thinking and improve students' ability to think critically [11].

\section{Conclusion}

The results of the conclusions of the material validator based on the indicators provided in teaching materials in the form of textbooks Basic Education Based on high-level thinking skills with validation carried out twice by each validator, obtained valid results with an average percentage score of $80,65 \%$. Then proceed with the results of the conclusion of the assessment by linguists using three aspects of assessment, namely the use of language, accuracy of language, and suitability of student development the results obtained are very valid, with an average score of $97.75 \%$. Then, as a conclusion from the presentation expert, the results were very valid, with an average score of $79.42 \%$. By referring to 3 validators and after doing two validations as a whole it can be stated that: (1) the design of teaching material development basics for non-school education based on high-level thinking skills is feasible to use, and (2) teaching materials for fundamentals of out-of-school education developed is valid used and meets the eligibility criteria as a learning material based on high-level thinking skills for the Fundamentals of Non-School Education Basics.

\section{Suggestions}

For supporting lecturers, the teaching material in the form of textbooks that are developed in essence can be used as an alternative teaching material to improve students' high-level thinking skills, especially on the six main topics, namely: PLS Concept, PLS Development in Indonesia, The legal basis of PLS in Indonesia, PLS Tasks and PLS Population Targets, and PLS Philosophy. Teaching materials in the form of textbooks The basics of PLS based on high-level thinking skills produced have not been widely applied throughout the first semester students, their spread is still very limited that is only the subject of research students. For this reason, it is recommended to lecturers who are able to implement teaching materials in the form of textbooks in all departments within the FIP UNIMED environment. 


\section{References}

[1] Permanasari, V. (2013), Efektivitas Pendekatan Pembelajaran Open-Ended terhadap Kemampuan Berpikir Matematis Siswa pada Materi Trigonometri Ditinjau dari Kreativitas Belajar Matematika Siswa. Jurnal Pendidikan Matematika Solusi, 1 (1). pp $1-7$.

[2] Rofiah,E., Aminah,N.S., dan Ekawati,E.Y. (2013), Penyusunan Instrumen Tes Kemampuan Berpikir Tingkat Tinggi Fisika pada Siswa SMP, Jurnal Pendidikan Fisika, 1, pp. 17-22.

[3] Heong, Y.M., Widad, Jailani, Razali, T., dan Mohaffyza, M. (2011), The Level of Marzano Higher Order Thinking Skills among Technical Education Students, International Journal of Science and Humanity, 1. pp.121-125.

[4] Susanti, A.T., Prayitno,B.A., dan Sudarisman,S. (2015), Pengaruh Model Problem Based Learninng Disertai Media Key Relation Chart terhadap Kemampuan Berpikir Kritis dan Kerjasama Siswa dalam Kelompok pada Kelas VIII SMP Negeri 14 Surakarta Tahun Pembelajaran 2012/2013, Jurnal Pendidikan Biologi7. pp. 1-13.

[5] Lewy., Zulkardi., dan Aisyah N. (2009), Pengembangan Soal Untuk Mengukur Kemampuan Berpikir Tingkat Tinggi Pokok Bahasan Barisan dan Deret Bilangan di Kelas IX Akselerasi SMP Xaverius Maria Palembang. Jurnal Pendidikan Matematika, 3 (2), pp. 4-6.

[6] Eko, Lesmono. (2008), Pengembangan lembar Kerja Siswa Berbasis Masalah untuk Meningkatkan.

[7] Husna. (2018), HOTS (High Order Thingking Skills) dan Kaitannya dengan Kemampuan Literasi Matematika. Prisma, 1. pp.170-176.

[8] Putra, N. (2015), Research \& Development. Jakarta: Raja Grafindo.

[9] Setyosari,P. (2010), Metode Penelitian Pendidikan dan Pengembangan. Jakarta: Prenada Media Group.

[10] Yani, A. (2019), Cara Mudah Menulis Soal HOTS. Bandung: Refika Aditama.

[11] Sani, R.A. (2019), Pembelajaran Berbasis Higher Order Thingking Skills (HOTS). Jakarta: Bumi Aksara. 